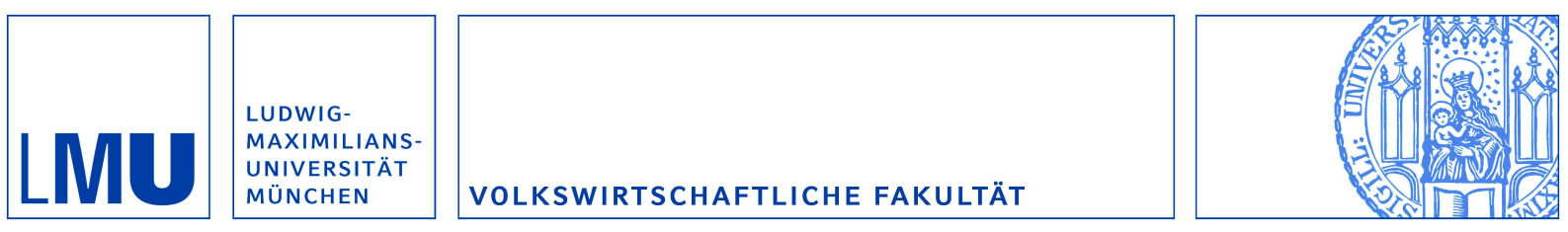

Marin, Dalia; Kaufmann, Daniel und Gorochowskij, Bogdan:

Barter in Transition Economies: Competing Explanations Confront Ukrainian Data

Munich Discussion Paper No. 2000-6

Department of Economics

University of Munich

Volkswirtschaftliche Fakultät

Ludwig-Maximilians-Universitäł München

Online at https://doi.org/10.5282/ubm/epub.63 


\title{
Barter in Transition Economies: Competing Explanations Confront Ukrainian Data
}

\author{
Dalia Marin \\ University of Munich, CEPR, and RECEP \\ Daniel Kaufmann \\ The World Bank \\ Bogdan Gorochowskij \\ Humboldt University Berlin
}

Januar 2000

This paper is a substantially revised version of an earlier paper which circulated under the title "Disorganization, Financial Squeeze, and Barter" in September 1998. Earlier versions of this paper were presented at the European Bank for Reconstruction and Development, at the CEPR International Workshop in Transition Economics in Prague and at the RECEP Conference on Economic and Social Reform in Russia: A European-Russian Dialogue in Moscow. We thank Alexis Giesen for very able research assistance and the Harvard Institute for International Development for financial and logistic support. 


\title{
Barter in Transition Economies: Competing Explanations Confront Ukrainian Data
}

\begin{abstract}
In this paper we survey the common explanations of barter in transition economies and expose them to detailed survey data on 165 barter deals in Ukraine in 1997. The evidence does not support the notion that soft budget constraints, lack of restructuring, or that the virtual economy are the driving forces behind barter. Further, tax avoidance is only weakly associated with the incidence of barter in Ukraine. We then explore an alternative explanation of barter as a mechanism to address transitional challenges where capital markets and economic institutions are poorly developed. First, barter helps to maintain production by creating a dealspecific collateral which softens the liquidity squeeze in the economy when credit enforcement is prohibitively costly. Second, barter helps to maintain production by preventing firms to be exploited by their input suppliers when suppliers' bargaining position is very strong due to high costs of switching suppliers. Thus, in the absence of trust and functioning capital markets barter is a self-enforcing response to imperfect input and financial markets in the former Soviet Union. The paper concludes by discussing potential long-term costs of barter arrangements, and by suggesting particular pitfalls of expansionary monetary policy in barter economies such as Ukraine and Russia.
\end{abstract}




\section{Introduction}

One of the most striking puzzles of the recent development in the former Soviet Union (FSU) is the rise of barter trade. In a barter trade goods are paid with goods or money surrogates rather than cash. Under central planning this form of trade was especially observed in international trade among CMEA countries as well as in EastWest trade. ${ }^{1}$ Barter in the domestic economy in Russia started to rise after macroeconomic stabilization in 1994 from 5 percent of GDP to 60 percent in 1998. ${ }^{2}$ Our survey in the Ukraine gives an estimate of barter in industrial sales of 51 percent in 1997. The importance of barter varies across transition economies. The World Business Environment Survey in 20 transition economies shows that Croatia exhibits the highest percent share of barter of 33 percent, Russia and the Ukraine show a barter share of about 24 percent and Central Europe like Hungary, Poland, and the Czech Republic have barter shares between 0.8 and 4.7 percent. It is also interesting to see that some of these countries experienced an increase in the importance of barter over time like Croatia, Russia and the Ukraine, while barter declined in Uzbekistan, Kazakhstan, and Moldova. In Uzbekistan the fall of barter was particularly pronounced. ${ }^{3}$

\footnotetext{
${ }^{1}$ see Marin (1990) for the importance of barter in East-West trade, and Marin and Schnitzer (1995) for an explanation.

${ }^{2}$ For the development of barter over time see Transition Report 1997, for a recent estimate for Russia see Commander and Mumssen (1998).

${ }^{3}$ The reason why the estimates of barter of Commander and Mumssen (1998) on Russia and our estimate on the Ukraine differ from the World Business Environment Survey estimates is that the former two studies include bartering firms only while the latter considers bartering as well as nonbartering firms.
} 
Table1:

Barter in Transition Economies

\begin{tabular}{|c|c|c|c|}
\hline & 1996 & 1999 & percent change \\
\hline Armenia & 2,9 & 2,9 & 0,0 \\
\hline Azerbajian & 5,1 & 4,0 & 0,2 \\
\hline Belarus & 13,1 & 13,9 & 0,7 \\
\hline Bulgaria & 4,0 & 4,2 & $-0,2$ \\
\hline Croatia & 21,7 & 32,8 & 11,5 \\
\hline Czech Republic & 3,8 & 3,3 & $-0,5$ \\
\hline Estonia & 5,5 & 4,1 & $-1,3$ \\
\hline Georgia & 6,8 & 5,2 & $-1,4$ \\
\hline Hungary & 1,7 & 0,8 & $-0,8$ \\
\hline Kazakhstan & 20,7 & 17,9 & $-2,8$ \\
\hline Kyrghiszistan & 16,5 & 17,4 & 1,8 \\
\hline Lithuania & 3,1 & 2,8 & 0,1 \\
\hline Moldova & 29,6 & 26,3 & $-1,3$ \\
\hline Poland & 3,9 & 4,7 & 0,7 \\
\hline Romania & 8,6 & 7,3 & $-0,3$ \\
\hline Russia & 23,5 & 24,1 & 1,4 \\
\hline Slovakia & 19,2 & 19,2 & 0,6 \\
\hline Slovenia & 17,4 & 16,3 & $-0,8$ \\
\hline Ukraine & 20,3 & 24,0 & 4,7 \\
\hline Uzbekistan & 23,2 & 10,2 & $-13,2$ \\
\hline Total & 12,5 & 12,1 & $-0,1$ \\
\hline
\end{tabular}

Source: World Business Environment Survey, World Bank-EBRD 1999.

Preliminary, not for citation at this stage. 
What explains the explosive increase of barter over time? Why does barter exist in some transition economies and not in others? In this paper we take a closer look at Ukraine which clearly stands out to be a transition economy in which barter plays a dominant role. By looking at one individual country we will try to understand the evolution of barter over time. ${ }^{4}$ We explore several explanations of barter in transition economies which have been raised in the recent debate on the phenomenon. Among these explanations are soft-budget constraint, tax avoidance, delay in restructuring, the virtual economy, and lock-in. Delay in privatization and inefficient governance structures are seen to lead to quantity targeting rather than profit maximization. The absence of hard budget constraints leads managers and workers to avoid the costs arising from restructuring by maintaining production in inefficient activities. Barter is seen to help to conceal the true market value of output. ${ }^{5}$ Furthermore, barter is seen by many experts to allow to avoid paying taxes by distorting the true value of profits. In addition, the banking sector is used as a tax collection agency by transferring firm's incoming cash on bank accounts to the state to pay for outstanding tax arrears. This way a payment in goods allows to circumvent paying taxes. The virtual economy argument claims that barter helps to pretend that the manufacturing sector in Russia is producing value while in fact it is not. A final explanation of the use of non-monetary market exchange which is complementary to the explanation of this paper accounts for its persistence over time once reciprocal exchange is established. When more people engage in barter, market search costs increase and thus it becomes harder to exchange goods for money and the incentive to maintain "personalized" exchange increases. Through this lock-in and network effect, this explanation points to possible long-term costs of using barter as an exchange system, because the latter system can persist even when it is inefficient. It cannot, however, explain, why barter started to exist in the first place in the former Soviet Union in $1994{ }^{6}$

We then proceed to explore an alternative explanation of barter in transition economies. This sees barter as an economic institution to cope with problems arising in the transition when the legal system and capital markets are poorly developed. In a recent paper Blanchard and Kremer (1997) argue that the large decline in output in the former Soviet Union has been caused by "disorganization" and hold-up problems. The economy suffers from a lack of trust. ${ }^{7}$ Disorganization arises in a "nofuture" environment when old relationships break down before new ones can be

\footnotetext{
${ }^{4}$ In Kaufmann and Marin (1999) we focus on an explanation of the pattern of barter across transition economies.

${ }^{5}$ The possibility of hiding in barter might make it an instrument for the unofficial economy and corruption. We explore the connection between barter, the unofficial economy, and corruption in more detail across transition economies in Kaufmann and Marin (1999). For the role of the unofficial economy to cope with the transition see Johnson, Kaufmann and Shleifer 1997.

${ }^{6}$ See R.E. Kranton (1996).

${ }^{7}$ see Johnson, Kaufmann, and Shleifer (1997) for why the official output fall might be overstated.
} 
established. We argue in this paper that having no cash and requiring a trade credit from their input suppliers gives intermediate producers bargaining power which helps them do deal with disorganization and the lack of trust in the economy. The buyer's lack of cash introduces also opportunities for hold-up on the other side of the transaction which helps to equalize bargaining power between the parties and to reduce distortions. However, it brings problems of its own, notably uncertainty about the enforceability of credit contracts, which can be dealt with by trading in barter. This way barter can mitigate contractual hazards when capital markets are imperfect and it makes financing of business activities possible which otherwise would not take place. Through this credit channel barter can prevent output from declining even more than it otherwise would.

The paper is organized in the following sections. Section 2 looks at competing explanations of barter and evaluates them against data of 165 barter deals in the Ukraine in 1997. The data come from three cities: Kyiv (50 percent), Zaporioshje (30 percent), and Dnipropetrovsk (20 percent). Section 3 then looks at the relationship between the trust problem and liquidity constraint in which the latter is a way to deal with an environment in which contracts are poorly enforced. Section 4 analyzes the relationship between inter-firm arrears and barter in which the latter is a way to deal with poorly functioning capital markets. Finally, section 5 concludes and discusses some policy options.

\section{Competing Explanations}

In this section we first look at some of the features of barter in the Ukraine based on our survey of 165 barter deals in three cities in the Ukraine in 1997 and then proceed to explore the most common explanations of barter.

Table 2 shows that barter accounts for on average 51 percent of firm's sales with a minimum barter share of 1 percent and a maximum share of 100 percent. The barter deals are typically large in size ranging between $\mathrm{U} \$ 10$ and $\mathrm{U} \$ 5.000 .000$ with a mean size of U\$ 145.534. Furthermore, barter occurs especially in the machinery and vehicle sector ( $48 \%$ of bartering firms are from this sector) and in the basic sector ( $24 \%$ of bartering firms). 
Table 2:

Descriptive Statistics

\begin{tabular}{lrrrr}
\hline & mean & min & max cases \\
\hline barter in percent of output & 51 & 0 & 100 & $220^{*}$ \\
size of barter deal in US-Dollars & 135.679 & 10 & 5.000 .000 & 150 \\
Industry classification & & & & \\
\multicolumn{1}{c}{$\begin{array}{l}\text { machinery and vehicles } \\
\text { basic industry }\end{array}$} & $\mathrm{D}=1$ & 48 observations & 165 \\
& $\mathrm{D}=1$ & 24 observations & 165 \\
\hline
\end{tabular}

"The number of firms exceeds the number of barter deals because each deal involves two firms (a seller and a buyer). The percentage given in the table is the mean over the total of selling as well as buying firms.

Source: Survey of 165 barter deals in Ukraine in 1997.

\section{Soft Budget Constraints and Restructuring}

Table 3 looks at the question whether barter can be explained by problems of corporate governance and/or mode of ownership. Are state-firms using barter more often than private firms? Do they try to avoid restructuring by using barter to conceal the true value of output as has been claimed? $?^{8}$ The table demonstrates that barter does not seem to be a phenomenon of state-owned enterprises. Newly established private firms show the same or higher barter exposure as state-owned firms or cooperatives. The average barter share of state enterprises is 56.6 percent and that of private firms 58.3 percent. In addition, Table 4 shows that there is no relationship between the barter intensity of the firm and the productivity of the firm, if at all the relationship is positive (the correlation coefficient is 0.05 ). This suggest that avoiding restructuring by inefficient and loss making firms is not the prime reason for barter. Table 4 looks also at the relationship between arrears and the efficiency level of the firm. The different types of arrears in percent of output do appear to be declining with the productivity level of the firm. However, the correlation coefficients between arrears and efficiency (given at the bottom of Table 4) are near zero and not significant at conventional levels except for the correlation between wage areas and productivity. This evidence suggests that neither soft

\footnotetext{
${ }^{8}$ See European Bank for Reconstruction and Development, Transition Report 1997, pp. 26-27
} 
budget constraints nor a reluctance to move into efficient activities seem to be the driving force behind barter. The data do suggest, however, that very large arrears (firm arrears of more than 50 percent of firm's output) tend to be a phenomenon of less efficient firms. 
Table 3:

\section{Ownership, Debt, and Barter}

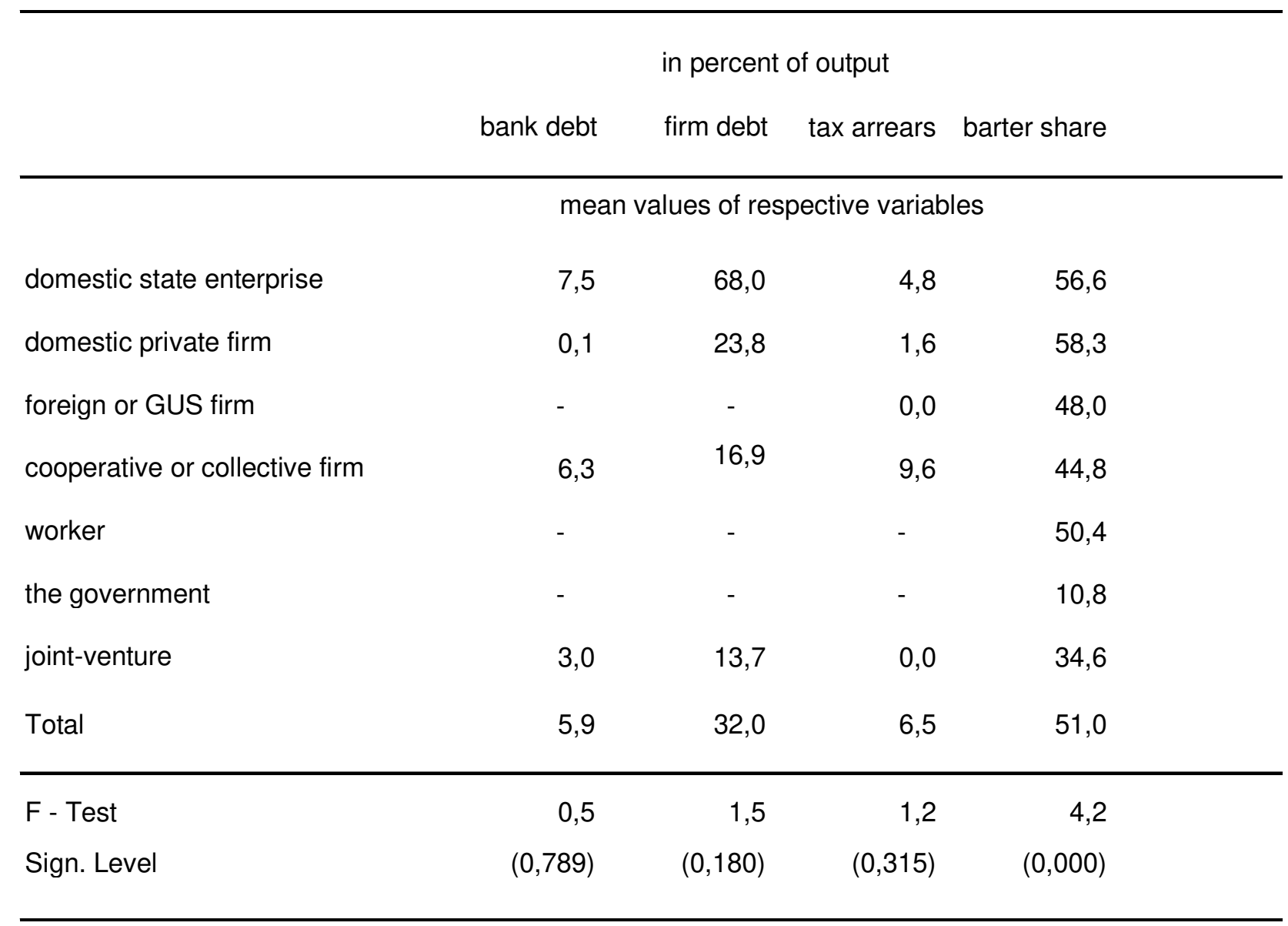

*The percentages in the table refer to the number of firms rather than the number of barter deals. The number of firms exceeds the number of barter deals because each deal involves two firms (a seller and a buyer). The percentages given in the table are the mean over the total of selling as well as buying firms.

Source: Survey of 165 barter deals in Ukraine in 1997. 
Table 4:

Barter, Arrears and Efficiency

\begin{tabular}{|c|c|c|c|}
\hline & mean & std. dev. & cases \\
\hline & \multicolumn{3}{|c|}{ barter share in percent of output } \\
\hline efficiency* $^{*}$ & 45,61 & 28,41 & 153 \\
\hline $\begin{array}{r}1.500-7.000 \\
7.100-15.000 \\
15.100-140.000\end{array}$ & $\begin{array}{l}48,18 \\
44,05 \\
44,17\end{array}$ & $\begin{array}{l}29,91 \\
27,59 \\
27,82\end{array}$ & $\begin{array}{l}57 \\
60 \\
36\end{array}$ \\
\hline \multirow[t]{2}{*}{$F=0,366$} & \multicolumn{3}{|c|}{ sign. level 0,694} \\
\hline & \multicolumn{3}{|c|}{ total arrears in percent of output } \\
\hline efficiency $^{*}$ & 41,42 & 101,07 & 138 \\
\hline $\begin{array}{r}1.500-7.000 \\
7.100-15.000 \\
15.100-140.000\end{array}$ & $\begin{array}{l}69,60 \\
17,89 \\
26,97\end{array}$ & $\begin{array}{r}150,16 \\
15,13 \\
38,44\end{array}$ & $\begin{array}{l}57 \\
48 \\
33\end{array}$ \\
\hline \multirow[t]{2}{*}{$F=4,024$} & \multicolumn{3}{|c|}{ sign. level 0,020} \\
\hline & \multicolumn{3}{|c|}{ firm arrears in percent of output } \\
\hline efficiency* $^{*}$ & 30,15 & 90,89 & 138 \\
\hline $\begin{array}{r}1.500-7.000 \\
7.100-15.000 \\
15.100-140.000\end{array}$ & $\begin{array}{l}53,88 \\
13,53 \\
13,32\end{array}$ & $\begin{array}{r}137,82 \\
14,56 \\
10,29\end{array}$ & $\begin{array}{l}57 \\
48 \\
33\end{array}$ \\
\hline \multirow[t]{2}{*}{$F=3,429$} & \multicolumn{3}{|c|}{ sign. level 0,035} \\
\hline & \multicolumn{3}{|c|}{ wage arrears in percent of output } \\
\hline efficiency $^{*}$ & 3,38 & 6,00 & 150 \\
\hline $\begin{array}{r}1.500-7.000 \\
7.100-15.000 \\
15.100-140.000\end{array}$ & $\begin{array}{l}6,78 \\
1,71 \\
0,63\end{array}$ & $\begin{array}{l}8,45 \\
1,80 \\
1,67\end{array}$ & $\begin{array}{l}57 \\
57 \\
36\end{array}$ \\
\hline \multirow[t]{2}{*}{$F=18,701$} & \multicolumn{3}{|c|}{ sign. level 0,000} \\
\hline & \multicolumn{3}{|c|}{ tax arrears in percent of output } \\
\hline efficiency $^{*}$ & 7,15 & 19,31 & 150 \\
\hline $\begin{array}{r}1.500-7.000 \\
7.100-15.000 \\
15.100-140.000\end{array}$ & $\begin{array}{r}8,94 \\
2,38 \\
11,88\end{array}$ & $\begin{array}{r}13,79 \\
6,25 \\
33,98\end{array}$ & $\begin{array}{l}57 \\
57 \\
36\end{array}$ \\
\hline$F=3,158$ & \multicolumn{3}{|c|}{ sign. level 0,045} \\
\hline
\end{tabular}

*Output in US\$ per employee

The Pearson correlation coefficient between the barter share and efficiency is 0.05 , between total arrears and efficiency -0.13 , between firm arrears and efficiency -0.12 , between wage arrears and efficiency -0.25 , and between tax arrears and efficiency -0.03 . Except for wage arrears none of the correlations are significant at conventional levels.

Source: Survey of 165 barter deals in Ukraine in 1997. 
In order to control for size effects in the relationship between productivity and barter on the one hand and productivity and arrears on the other Table 5 calculates the relevant correlation coefficients for different firm sizes. The correlation between barter and efficiency is near zero and insignificant. However, the correlation between the different types of arrears and efficiency becomes more negative and more significant for all firm sizes except for medium sized firms.

Table 5:

\section{Barter, Arrears and Efficiency by Firm Size}

\begin{tabular}{|c|c|c|c|c|c|}
\hline & barter share & total arrears & firm arrears & wage arrears & tax arrears \\
\hline \multicolumn{6}{|c|}{$\underline{\text { small firms }}{ }^{1)}$} \\
\hline efficency* $^{*}$ & $\begin{array}{c}0,09 \\
(0,43)\end{array}$ & $\begin{array}{l}-0,27 \\
(0,04)\end{array}$ & $\begin{array}{l}-0,22 \\
(0,10)\end{array}$ & $\begin{array}{l}-0,33 \\
(0,00)\end{array}$ & $\begin{array}{l}-0,20 \\
(0,10)\end{array}$ \\
\hline \multicolumn{6}{|l|}{$\frac{\underline{\text { medium }}}{\underline{\text { firms }^{2)}}}$} \\
\hline efficency* $^{*}$ & $\begin{array}{l}-0,19 \\
(0,22)\end{array}$ & $\begin{array}{c}0,28 \\
(0,08)\end{array}$ & $\begin{array}{l}-0,19 \\
(0,22)\end{array}$ & $\begin{array}{c}0,00 \\
(1,00)\end{array}$ & $\begin{array}{c}0,39 \\
(0,01)\end{array}$ \\
\hline \multicolumn{6}{|c|}{ large firms ${ }^{3)}$} \\
\hline efficency* $^{*}$ & $\begin{array}{c}0,01 \\
(0,98)\end{array}$ & $\begin{array}{l}-0,31 \\
(0,08)\end{array}$ & $\begin{array}{l}-0,31 \\
(0,08)\end{array}$ & $\begin{array}{l}-0,35 \\
(0,05)\end{array}$ & $\begin{array}{l}-0,35 \\
(0,04)\end{array}$ \\
\hline
\end{tabular}

*Output in US\$ per employee

The number s are Pearson correlation coefficients and the number in brackets give the significant levels.

1) Output level between 0 and 4 billion US\$

2) Output level between 4 and 20 billion US\$

3) Output level between 20 and 500 billion US\$

Source: Survey of 165 barter deals among 55 Ukrainian firms in 1997 


\section{The Virtual Economy}

Next, we turn to the virtual economy argument of Gaddy \& Ickes (1998). The argument rests on the assumption that the manufacturing sector is valuesubstracting, but that most participants in the economy have an interest to pretend that it is not. Barter allows the parties to pretend by allowing the manufacturing sector to sell its output at a higher price than its market value and the value-adding natural resource sector (Gazprom) to accept this overpricing out of a lack of other opportunities. But if the natural resource sector is producing valuable output, why has the sector nothing better to do than to subsidize the manufacturing sector? Let us pretend for a moment that the virtual economy argument does make economic sense (which it does not), is it actually true?

We can answer this question from our survey data, since we have information on the percentage price difference between the barter price and the cash price for each of the 165 barter deals in the sample. We have this information for both sides (the "sale" and the "goods payment") of each barter deal so that we can calculate the net terms of trade effect of barter. Table 6 aggregates the 165 barter deals into 8 sectors and looks at their pricing behavior in barter compared to cash deals. The table distinguishes whether the sector is on the selling or buying end of the transaction. SCASH is the percentage difference between the barter price and the cash price on the "sale" side of the barter deal. PCASH is the percentage difference between the barter price and the cash price on the "goods payment" of the barter deal. ${ }^{9}$ TOT measures the net terms of trade effect and is calculated by TOT $=$ SCASH - PCASH. When the sector is on the selling end of the transaction and TOT takes a positive value, then barter allows the sector to shift the terms of trade in its favor. When the sector is on the buying end of the transaction and TOT takes a positive value, then barter shifts the terms of trade in its disfavor.

If the virtual economy argument were valid, we would expect that manufacturing sectors like textiles and leather, machinery and vehicles, and chemicals to shift the terms of trade in their favor, while the natural resource sectors like electricity \& gas, coke and petroleum would see the terms of trade move against them. What appears from Table 6 is that there is no systematic difference in the pricing behavior within barter across sectors (the F-test of the Analysis of Variance (ANOVA) is not statistically significant at conventional levels). Take the example of machinery and vehicles. When this sector is on the selling end of the barter deal, it overprices its output on average by 3.66 percent relative to cash deals and is

\footnotetext{
${ }^{9}$ We obtained this information from the following question: „What is the percentage difference between the price you charge/you are charged in this barter deal as compared to the typical price you charge/you are charged for the same product in cash deals?"“
} 
overpriced on the "goods payment" by 0.91 percent on average, so that the sector's net benefit from barter is 2.75 percent (in terms of its cash price). So far so good. But the same appears to be true for the natural resource sector like electricity and gas. This sector's net benefit from barter is 4.12 percent (in terms of its cash price). What seems to matter here for the pricing behavior within barter is not the sector, but whether the sector is on the selling or buying end of the transaction. Take again the example of machinery and vehicles. When this sector is on the buying end of the barter deal, it pays more for the "sale" by 3.46 percent on average and sells its "good payment" at a 5.06 percent discount compared to cash deals, so that the sector's net loss from barter is 8.52 percent on average. This net loss from barter appears to be happening in all the other sectors as well except for electricity and gas, when the sector is a buyer rather than a seller. It appears then that the sectors gain from barter when they sell and they loose from barter when they buy. ${ }^{10}$ The only sector that seems to be gaining from barter independent of its buying or selling status appears to be the natural resource sector electricity and gas. This is just the opposite from what we would have expected if we believed in the virtual economy argument of Russia's non-cash economy.

${ }^{10}$ Marin and Schnitzer (1999) explain this pricing behavior by hold-up and incentive problems. 
Table 6:

\section{Pricing Behavior of Sectors}

\begin{tabular}{|c|c|c|c|c|c|c|c|}
\hline & & \multicolumn{3}{|c|}{ selling sector } & \multicolumn{3}{|c|}{ buying sector } \\
\hline & & scash $^{1)}$ & pcash $^{2)}$ & tot $^{3)}$ & scash & pcash & tot \\
\hline \multirow{3}{*}{ electricity \& gas } & mean & 0,00 & $-4,12$ & 4,12 & 3,78 & 7,42 & $-3,64$ \\
\hline & std. dev. & 0,00 & 8,52 & 8,52 & 8,80 & 45,06 & 42,11 \\
\hline & $\mathrm{N}$ & 17 & 17 & 17 & 18 & 18 & 18 \\
\hline \multirow{3}{*}{ coke \& petroleum } & mean & 5,48 & 1,45 & 4,03 & 1,13 & $-1,31$ & 2,44 \\
\hline & std. dev. & 14,45 & 10,28 & 8,37 & 5,50 & 6,54 & 6,57 \\
\hline & $\mathrm{N}$ & 13 & 13 & 13 & 16 & 16 & 16 \\
\hline \multirow{3}{*}{$\begin{array}{l}\text { metal ores \& other } \\
\text { non-metallic minerals }\end{array}$} & mean & 5,00 & $-1,29$ & 6,29 & 2,50 & 0,58 & 1,92 \\
\hline & std. dev. & 10,16 & 6,05 & 10,05 & 8,09 & 17,02 & 18,29 \\
\hline & $\mathrm{N}$ & 17 & 17 & 17 & 18 & 18 & 18 \\
\hline \multirow{3}{*}{ food \& beverages } & mean & 2,64 & 1,00 & 1,64 & 3,03 & $-2,47$ & 5,51 \\
\hline & std. dev. & 6,53 & 38,45 & 35,75 & 9,45 & 15,38 & 14,09 \\
\hline & $\mathrm{N}$ & 27 & 27 & 27 & 36 & 36 & 36 \\
\hline \multirow{3}{*}{ textiles \& leather } & mean & 1,86 & 0,26 & 1,61 & 5,21 & $-4,17$ & 9,38 \\
\hline & std. dev. & 8,46 & 6,86 & 9,99 & 7,11 & 7,93 & 9,66 \\
\hline & $\mathrm{N}$ & 16 & 16 & 16 & 12 & 12 & 12 \\
\hline \multirow{3}{*}{ mashinery \& vehicles } & mean & 3,66 & 0,91 & 2,75 & 3,46 & $-5,06$ & 8,52 \\
\hline & std. dev. & 7,41 & 10,64 & 13,51 & 7,67 & 9,96 & 11,40 \\
\hline & $\mathrm{N}$ & 28 & 28 & 28 & 30 & 30 & 30 \\
\hline \multirow{3}{*}{ chemicals } & mean & 6,08 & $-3,60$ & 9,68 & 7,19 & 0,07 & 7,12 \\
\hline & std. dev. & 9,49 & 12,50 & 11,18 & 9,47 & 12,01 & 8,59 \\
\hline & $\mathrm{N}$ & 22 & 22 & 22 & 15 & 15 & 15 \\
\hline \multirow{3}{*}{ services } & mean & 2,83 & $-4,04$ & 6,86 & 0,00 & $-10,00$ & 10,00 \\
\hline & std. dev. & 6,54 & 17,72 & 16,27 & 0,00 & 0,00 & 0,00 \\
\hline & $\mathrm{N}$ & 23 & 23 & 23 & 1 & 1 & 1 \\
\hline \multirow{3}{*}{ total } & mean & 3,43 & $-1,16$ & 4,59 & 3,52 & $-1,21$ & 4,73 \\
\hline & std. dev. & 8,30 & 18,63 & 18,07 & 8,26 & 19,66 & 18,86 \\
\hline & $\mathrm{N}$ & 163 & 163 & 163 & 146 & 146 & 146 \\
\hline \multirow[t]{2}{*}{ Anova } & F-test & 1,08 & 0,33 & 0,52 & 0,76 & 0,77 & 0,93 \\
\hline & sign. level & $(0,382)$ & $(0,937)$ & $(0,817)$ & $(0,619)$ & $(0,614)$ & $(0,489)$ \\
\hline
\end{tabular}

1) difference between the barter price and the cash price in percent of the cash price in the "sale" side of the barter deal.

2) difference between the barter price and the cash price in percent of the cash price in the "goods payment" of the barter deal.

3) terms of trade tot $=$ scash - pcash 


\section{Taxes}

We turn now to the tax incentives for barter. We have ask the firms whether there was a tax advantage reason for using barter. Only 9.5 percent of the barter deals were motivated by taxes in which firms answered that taxes were a very important or important reason to engage in this form of exchange (see Table 7). Even if one takes into account that the data have some noise, it does suggest that tax reasons are not the major motivation behind barter. ${ }^{11}$

The empirical evidence so far indicates that barter is a dominant phenomenon of the former Soviet Union. Furthermore, the tables suggest that the most common explanations of barter - the lack of market discipline, lack of restructuring, the virtual economy, and tax avoidance - are not supported by the data. An explanation of barter has therefore to be found somewhere else. More specifically, any explanation of barter has to address the following two questions: First, why would parties want to tie two deals? Second, why would parties want to pay in goods rather than money? Before we come to a specific answer to these questions we turn to the answers given by the firms themselves.

In Table 7 it can be seen that barter is predominantly motivated by financial considerations. In 87.5 percent of the deals a key reason for using barter was that there was no cash available. In 29 percent of the barter deals the firm could not get a loan even when ready to pay a high interest rate. ${ }^{12}$ In 72 percent of the cases the party used barter, because she expected to be paid faster in this form of exchange. Also an important reason for barter seems to be to smooth production. In 66 percent of the cases the firm could use goods stored as inventories as means of payment in barter deals and in 12.5 percent of the cases the firm used barter, because it was the only way to maintain production. ${ }^{13}$ Additionally, barter was used as a way to change the relative price for the good in question in 20.8 percent of the deals.

\footnotetext{
${ }^{11}$ Kaufmann and Marin (1999) look at the tax motive for barter across 20 transition economies in more detail.

${ }^{12}$ The answers do not include cases when the firm did not take a bank loan, because of too high interest rates.

${ }^{13}$ We added this question to the survey during the period of firm interviews, because firms often spontaneously gave this as a reason for why they engage in barter. The later inclusion into the survey leads to an underestimation of the true response to the question "maintaining production".
} 
Table 7:

Motives for Barter

1997

in percent ${ }^{1}$

\begin{tabular}{lr}
\hline no cash & 87,5 \\
no bank loan & 29,1 \\
no trust in the value of money & 6,0 \\
faster payment compared to cash payment & 72,1 \\
no struggle with other creditors & 7,8 \\
no courts to enforce rights & 6,0 \\
to maintain production & 12,5 \\
goods in stock could be used & 66,1 \\
liquid good & 1,8 \\
better deal on the price in barter & 20,8 \\
reducing the tax burden & 9,5 \\
avoiding controls on foreign trade & 1,8 \\
reducing regulations & 6,0 \\
capital flight to the west & 0,0 \\
state pressure & 1,8 \\
others & 1,2 \\
\hline
\end{tabular}

1) answers have been ranked between very important and irrelevant. The percentages give very important responses.

Source: Survey of 165 barter deals in Ukraine in 1997

In the following two sections we will look at an alternative explanation which takes into account that barter is primarily driven by financial reasons. Firms might want to tie two deals and they might want to pay in goods rather than money because by doing so they can solve incentive and hold-up problems which otherwise would prevent trade from taking place at all. In the next section we will argue that having no cash turns out to be a mechanism to cope with disorganization and holdup when legal enforcement of contracts is poorly developed. In section 4 we will argue that barter creates a deal specific collateral and that this is a way of dealing with the problem of creditworthiness of firms. 


\section{Disorganization and Liquidity Constraint}

In a recent paper Blanchard and Kremer (1997) explain the rapid output decline in the former Soviet Union by disorganization and hold-up problems. Central planning was characterized by a complex set of specific relations between firms. Many firms had only one

Table 8:

\section{Lock-In:}

Business Alternatives

\begin{tabular}{lll}
\hline & sale & goods payment \\
\hline no alternative & & in percent \\
a few alternatives & 20,2 & 6,0 \\
many alternatives & 36,9 & 32,1 \\
& 41,1 & 60,1 \\
\hline
\end{tabular}

Source: Survey of 165 barter deals in Ukraine in 1997.

supplier from which to buy and knew of only one or a few buyers to whom to sell. This picture of little outside opportunities is still observed in the Ukraine in 1997. In 20 percent of the sales within barter deals the parties had no alternative partner and in 37 percent of the sales only a few alternative partners to carry out the business.

Such an environment with little outside opportunities - called specificity typically creates hold-up problems and opens room for bargaining. Under central planning the main instrument to enforce production and delivery of goods was the coercive power of the state. Transition eliminated the central planner and thus the instrument to limit the adverse effects of specificity without creating institutions to deal with specificity such as vertical integration and the range of contracts that exist in market economies. Furthermore, in times of transition the anticipation of changing business partners and the disappearance of firms shortens horizons and reduces the scope for long term relationships. Thus, in such a "no future" environment a typical mechanism to constraint opportunistic behavior such as reputation does not work. Blanchard and Kremer (henceforth BK) argue that specificity in the relations between firms together with incompleteness of contracts results in disorganization - the breakdown of many economic relations before new ones can be established - which in turn explains the large output losses.

In the BK model specificity arises in a chain of production with a large number of stages. Each buyer along the chain knows only the supplier it was paired with under 
central planning. The primary input supplier has an alternative use for the input while all intermediate producers along the chain of production are assumed to be able to sell to the next following buyer only. BK formulate the hold up problem by assuming that it is impossible for each firm in the chain to sign a contract with the buyer (the next firm in the chain) before it has produced the good. Each firm must first buy inputs and produce, and only then - once the cost of producing is sunk - can strike a bargain with the next producer in the chain. At this stage, however, each intermediate producer's reservation value is zero and thus the next producer in the chain can "hold him up" and exploit his dependency by offering to purchase the good at a price only which does not cover each intermediate producer's costs. The fear of being "held-up" by the following firm each intermediate producer will stop to deliver inputs and thus the chain of production breaks down. Output collapses due to a shortage of inputs. In the BK model output collapses because firm relations are specific (the intermediate producers cannot sell the good to someone else) and because contracts are incomplete (each intermediate producer must produce its intermediate good before bargaining over the price for the input with the next producer along the chain). If the government retained its coercive power it could force suppliers to deliver and thus output would not decline.

Is there another mechanism than the coercive power of the state by which intermediate producers can be induced to trade inputs by preventing producers further down the chain from reneging and renegotiating the price? Marin and Schnitzer (1999) (henceforth MS) claim yes in a model which introduces liquidity and credit constraints into a BK type of production chain. Analogous to BK they consider a good which requires $n$ steps of production. In contrast to BK, MS consider a situation in which the supplier holds up the buyer rather than the other way around. In MS formulation the buyer makes a firm-specific investment in order to find an adequate input supplier (see Figure 1). This investment takes place at date 0.9 . At date 1.0 when the supplier delivers the input they negotiate over the input price. At this stage the buyer's investment is already sunk and not taken into account in the bargaining over the input price. Thus, the buyer might not invest in finding a supplier relationship because these costs are not taken into account. This is what constitutes the hold-up problem on the buyer's side. MS claim that this formulation of the hold-up problem on the buyer's rather than the supplier's side to be more plausible in the context of the former Soviet Union, since input suppliers are on the short side of the market and thus input buyers have to spend time and money in order to find adequate suppliers and to establish a business relationship. ${ }^{14}$

\footnotetext{
${ }^{14}$ MS provide empirical evidence which supports this formulation of the hold-up problem on the buyer's side.
} 
Figure 1

\section{Sequence of Events}

\begin{tabular}{|c|c|c|}
\hline date & action & state \\
\hline
\end{tabular}

date 0.9

buyer makes investment

to find supplier

supplier holds-up

buyer;

the

input

bargaining power on

supplier's side due to

shortage

date 1.0

supplier and buyer negotiate over input price

input good delivered but not paid

buyer holds-up supplier;

bargaining power on the buyer's side due to

costly

credit enforcement

date 1.1

buyer offers to pay a reduced price for the input 
MS assume further that the intermediate producer has no cash to pay for the input at date 1.0. He requires a trade credit from the input supplier which he can repay when he sell the input to the next firm. In order to make sure that his trade credit is repaid, the input supplier has to incur credit enforcement costs (he has to involve legal firms or the Mafia). MS then show that the fact that the intermediate producer has no cash to pay for the input and thus requires a trade credit gives the input purchaser some countervailing bargaining power. This bargaining power in turn reduces the possibility that the input supplier can exploit the input purchaser's need for the input. More specifically, since the buyer has no cash to pay for the input upon delivery at date 1.0, once the input supplier delivers the input, the bargaining power reverses and shifts to the buyer. Now the input supplier has to worry of being paid (see Figure 1). When it comes to paying for the input after the input buyer has realized his profits from selling the input to the next firm at date 1.1 (which the input seller is assumed to be observing), the input buyer will hold up now the input seller and renegotiates the price for the input. He will try to lower the input price by the enforcement costs which the seller has to incur if the buyer does not pay voluntarily. In equilibrium the input seller will accept this lower price, since his alternative is to insist on the original price and to involve the Mafia.

However, the input supplier could attempt to compensate for this future price reduction by the buyer at date 1.1 by raising its input price at date 1.0 when he delivers the input. MS then show that marking up the input price at date 1.0 in anticipation of the future price renegotiations will be possible only at low credit enforcement costs. When these costs become sufficiently large, the buyer's liquidity constraint will make it impossible for the supplier to pass on these costs to him. The reason is that the most the buyer can pay for the input is the cash he himself realizes from selling the intermediate good to the next buyer. If enforcement costs are sufficiently large the input buyer's cash from the sale to the next firm will not be enough to cover these costs. This is the circumstance when the input buyer can exploit the fact that he is liquidity constraint to shift the surplus in his favor and thus prevent to be held up by the input supplier.

When credit enforcement costs become too large, however, the input supplier will refuse to participate in the deal, since he cannot expect a positive profit. From this story of the model MS predict a hump shaped relationship between the firm's output growth and credit enforcement costs. The output decline will be less pronounced for firms short of cash. Firms short of cash can use their liquidity constraint in the bargaining to prevent to be held-up by their input suppliers. When this constraint becomes too large, however, it may be too costly for the supplier to enforce payment and thus output declines due to a shortage of credit.

If the intermediate producer's liquidity constraint is alleviating the hold-up problem, what is then the role of barter? Barter becomes important when credit 
enforcement becomes so costly that input suppliers will refuse to participate in the deal. Thus, if the input buyer has no cash and requires a trade credit from the input supplier, but the legal system to enforce payment is poorly developed, a potentially valuable transaction does not take place. Under these circumstances barter can help to maintain production. Barter introduces a hostage, a commitment devise that prevents the buyer from fully exploiting his bargaining power. ${ }^{15}$ More specifically, when enforcement costs become prohibitively costly for the input supplier to participate in the deal, introducing a second profitable deal in the form of the goods payment allows the input buyer to commit not to exploit his bargaining power and to shift some of the profit back to the input supplier to make him participate in the deal. Barter is a self enforcing arrangement which makes the intermediate producers along the chain of production to loose from reneging the contract. This way barter helps to cope with specificity without relying on the legal system ${ }^{16}$. From this story MS predict a hump shaped relationship between the firm's output growth and the firm's exposure to barter.

In order to see whether this story makes sense empirically we will look at the relationship between the firm's change in output and the extend of the hold-up and the credit problem and the firm's exposure to barter. There are three implications. First, the more severe the hold-up problem, the lower will be the firm's output growth due to the breakdown of business relationships in response to a lack of trust. Second, the firm's output growth is expected to be larger for intermediate levels of credit enforcement costs and to be lower when the credit problem becomes very large (hump shaped relation). Third, the firm's output growth is expected to be larger for lower levels of barter exposure and to be lower when the barter exposure becomes very large (hump shaped relation).

We gathered data of 165 barter deals in 1997. Although the unit of analysis of the survey is a barter deal, the survey includes information on the two firms involved in each deal as well. We use these firm level information in the sample to look at the performance of firms. First, we construct an output growth variable. This variable is defined by the growth of output between 1994 and 1996 of an individual firm relative to the average growth rate between 1994 and 1996 for the total sample of the firms. We look also at the growth rate of output of the firm relative to the growth rate of GDP in the same period. We report both results in Table 9.

\footnotetext{
${ }^{15}$ Oliver Williamson introduced the concept of a hostage to facilitate exchange, see Williamson (1983).

${ }^{16}$ Greif and Kandel (1994), Hay and Shleifer (1998), and Johnson, Kaufmann and Shleifer (1997) point out that the deficiencies of the legal system are more pronounced in the FSU compared to the early TE.
} 
Table 9:

\section{Barter and Output Decline}

\begin{tabular}{|c|c|c|c|c|c|c|}
\hline & & \multicolumn{2}{|c|}{ firm's output to GDP growth ${ }^{1)}$} & \multicolumn{3}{|c|}{ firm's output to sample growth ${ }^{2)}$} \\
\hline & & mean & std. dev. & mean & std. dev. & cases \\
\hline \multirow[t]{5}{*}{1.} & firm arrears & 0,15 & 4,42 & 3,09 & 15,73 & 138 \\
\hline & $0 \%-10 \%$ & $-0,59$ & 1,71 & 0,46 & 6,08 & 66 \\
\hline & $10 \%-20 \%$ & 1,76 & 7,88 & 8,81 & 28,10 & 33 \\
\hline & $20 \%-626 \%$ & $-0,04$ & 2,98 & 2,24 & 15,73 & 45 \\
\hline & & $F=3.17$ & sign. level 0.045 & $F=3.17$ & sign. level & \\
\hline \multirow[t]{5}{*}{2.} & barter share & 0,01 & 4,2 & 2,60 & 15,0 & 153 \\
\hline & $0 \%-20 \%$ & $-0,31$ & 1,9 & 1,46 & 6,7 & 46 \\
\hline & $20 \%-60 \%$ & 1,37 & 6,4 & 7,43 & 22,8 & 58 \\
\hline & $60 \%-100 \%$ & $-1,30$ & 0,4 & $-2,05$ & 1,3 & 49 \\
\hline & & $F=5.84$ & sign. level 0.004 & $F=5.84$ & sign. level & \\
\hline \multirow[t]{5}{*}{3.} & complexity $^{3)}$ & 0,14 & 4,4 & 3,05 & 16,6 & 141 \\
\hline & $.34-.78$ & 1,84 & 8,0 & 9,10 & 28,4 & 33 \\
\hline & $.79-.83$ & 0,48 & 2,9 & 4,28 & 10,4 & 36 \\
\hline & $.84-.92$ & $-0,82$ & 1,6 & $-0,35$ & 5,5 & 72 \\
\hline & & $F=4.543$ & sign. level 0.012 & $F=5.84$ & sign. level & \\
\hline 4. & ownership & 0,01 & 4,2 & 2,60 & 15,0 & 153 \\
\hline & state & 0,14 & 2,9 & 3,06 & 10,2 & 40 \\
\hline & privat & $-0,85$ & 1,2 & $-0,47$ & 4,4 & 12 \\
\hline & cooperative & 0,16 & 5,1 & 3,12 & 18,1 & 92 \\
\hline & joint-venture & $-0,92$ & 0,1 & $-0,70$ & 0,2 & 9 \\
\hline & & $F=0.356$ & sign. level 0.785 & $F=0.356$ & sign. level & \\
\hline
\end{tabular}

1) percentage difference between the growth rate of firm's output and GDP growth in the period 1994 - 1996.

2) percentage difference between the growth rate of firm's output and output growth of sample firms in the period 1994 - 1996.

3) see text for definition

Source: Survey of 165 barter deals in Ukraine in 1997 
We first look at disorganization and the lack of trust as a reason for the output decline. We measure these problems with BK's index of complexity. According to their theory the hold-up problem becomes more severe and thus the decline in output more pronounced for goods with more complex production processes. Their measure of complexity is constructed on the bases of the 1990 "100-sector" inputoutput table for Russia. Complexity is equal to zero if the sector uses only one input from another sector and it tends to one if the sector uses many inputs in equal proportions. We matched the ISIC sector of our bartering firms with the sector of the complexity index given by BK. This measure is obviously full of noise for several reasons. BK's complexity index is based on the Russian input-output structure which might differ from that in the Ukraine. Further noise might be introduced because the production structure in the Ukraine might have changed since 1990. Finally, the ISIC classification of our sample could not always be perfectly matched with BK's classification of the index. In spite of all these caveats, we could reproduce BK's findings with firm level data. Table 6 reports that the firm's output growth becomes smaller compared to GDP growth of the economy when the firm's production is more complex. Firms producing goods which rank low in the complexity index increased their output by 1.8 percentage points compared to the economy as a whole, while the opposite was true for firms producing goods which ranked high on the complexity scale. Again, the same picture emerges when the firm's output growth is compared with the average growth of all firms in the sample rather than the economy as a whole. The association between the firms relative growth and the complexity measure is highly significant.

Next, we look at the credit problem. We measure the credit enforcement costs by the amount of arrears the firm has accumulated. The larger the accumulated arrears, the more likely it is that the firm does not fulfill its debt obligations and thus the larger are the credit enforcement costs assumed to be. ${ }^{17}$ As Table 9 shows there is indeed a hump shaped behavior between output growth and firm arrears. When arrears are small or very large the firm did less well in terms of output than the economy as a whole or the total sample of firms, while it exhibits a relative larger output growth for intermediate levels of arrears.

Furthermore, Table 9 shows that firms with a share of barter in output of up to $20 \%$ had a growth rate of output of 0.3 percentage points lower than the total economy, while firms with a barter share between $20 \%$ and $60 \%$ experienced a growth rate of 1.37 percentage points higher than the total economy. However, when the exposure to barter becomes too large (exceeds 60\%), then the firm's output

\footnotetext{
${ }^{17}$ Arrears are assumed to measure the firm 's current and future creditworthiness, since firms with large arrears must have been perceived as creditworthy to get into this state.
} 
appears to have grown 1.29 percentage points less than the economy as a whole. These findings suggest that there is an optimal level of barter at which the output decline is minimized. The relationship between output growth and barter exposure is statistically significant at conventional levels. The same picture emerges when the firm's output growth is related to the growth of the total sample of firms rather than to the economy as a whole. ${ }^{18}$

We also investigated the influence of ownership patterns. It appears that private enterprises are those with the least impressive performance in terms of output growth. The relationship between ownership pattern and relative output growth is not significant at conventional levels, however. ${ }^{19}$

\section{Inter-firm Arrears and Barter}

The literature on inter-firm debt in transition economies asks the following question. Why are firms giving loans to other firms when the same firms are not considered creditworthy enough by the banks and therefore do not get loans from banks? The answer that is most commonly given is the absence of market discipline. State-owned firms who are seen to show the highest inter-firm debt are seen to be able to get loans from other firms because of the soft budget constraint. But if the state-owned firms are creditworthy because of the backing of the government, they are expected to be the least credit constrained and thus to show the highest bank debt. As Table 3 shows, in our sample of bartering firms this is indeed the case. State-owned firms appear to have on average higher bank debt (7.5 percent of output) while private firms have negligible bank debt outstanding ( 0.1 percent of output). However, state owned firms show also the highest inter-firm arrears compared to private firms (68 percent and 24 percent of output, respectively). This suggests that state firms used their privileged status of creditworthiness to get cash credit from banks as well as trade credit from other firms.

An explanation for the phenomenon of inter-firm debt cannot, however, rest exclusively on the argument of soft-budget constraint. Inter-firm arrears are not a phenomenon of state firms alone. In our sample of bartering firms only 29 percent

\footnotetext{
${ }^{18}$ Table 9 gives univariate association between the relevant variables. We obtain qualitative similar results in a multivariate analysis which controls for other factors influencing output growth, see Marin and Schnitzer (1999).

${ }^{19}$ As we show in Table 3 and in the next section private firms where those which were hardest hit by the liquidity squeeze in the economy which might have inhibited their growth. Furthermore, the result might also be due to a selection bias in the sample, since the sample consists of bartering firms only. In Kaufmann and Marin (1999) we examine the difference between bartering and non-bartering firms using a sample of 20 transition economies.
} 
are state controlled. There must be additional forces at work here, which go beyond the lack of market discipline.

Capital and credit market do not function well in transition economies for a variety of reasons. Creditors are inexperienced with credit evaluation. Banks have difficulties in distinguishing bad from good debtors. There is no history to allow them to judge credit risk because of the drastic changes in the environment. In some of the transforming economies a bankruptcy law has not yet been introduced. Defaulting on debt repayment remains without consequences and therefore firms have little incentive to repay their loans from banks.

Many experts have suggested that one of the solutions to inter-firm debt is to restore the creditworthiness of firms by introducing a bankruptcy procedure. But in many countries like Hungary and Ukraine, for example, a bankruptcy law has been introduced and inter-firm debt has not stopped from rising. Furthermore, a study by Mitchell (1993) suggests that the introduction of a bankruptcy law by itself will not improve debt repayment because creditors did not use the bankruptcy procedure to get to their money. Among other factors Mitchell's

explanation for creditor passivity is the low expected value of their claims net of bankruptcy costs. This is due to the poor state or vintage of the capital stock of a debtor firm, the absence of a market for capital, and the priority assigned to a creditor in a bankruptcy relative to the ordering of other creditors. Mitchell's explanation suggests that inter-firm debt is not going to go away with the introduction of a bankruptcy law and that creditor passivity prevents bankruptcy from restoring the creditworthiness of firms.

The question remains: Why are firms able to give loans to other firms when the banking sector is reluctant to provide capital in spite of the availability of a bankruptcy procedure to pursue non paying debtors? The possibility of undertaking a business in form of barter trade becomes important in this context. In a barter trade one firm gives a trade credit to another firm which is repaid in goods rather than money. Barter trade offers the following advantages. ${ }^{20}$

First, barter does not attempt to improve the overall creditworthiness of firms (as in bankruptcy) but rather restores the creditworthiness of the firm for one specific deal. In a barter deal a deal-specific collateral is created in the form of the future goods payment. Depending on the degree of the credit problem of the debtor, the creditor can choose the value of the collateral relative to the trade credit that he gives to the debtor. This way the debtor's creditworthiness is restored for one specific deal. Giving a trade credit in the form of a barter deal is available to firms only, since banks are not allowed to engage in the trading business.

\footnotetext{
${ }^{20}$ For barter as a finance instrument in international trade see Marin and Schnitzer (1997).
} 
Second, in the early stages of transition barter trade can compensate for creditors' passivity. Instead of relying on the low and unknown liquidation value of the firm (as in bankruptcy), the creditor and debtor create a deal-specific collateral of positive and known value. Furthermore, in a barter trade the creditor does not need to share the benefits from her legal actions with other creditors. In a barter deal the creditor obtains property rights on goods - which effectively means that she does not need to queue with other creditors for the money. Compared to bankruptcy, in a barter trade there is no priority ordering of creditors. This makes payment in goods a superior credit enforcement mechanism compared to payment in money.

Thirdly, barter is a more information-intensive form of financing. Typically a trade credit is given between two firms which know each other from previous transactions (one firm is a producer and the other firm is an input supplier).

Table 10 looks at the trade credit features within barter deals. In 36.9 percent of the deals a trade credit was given within the barter deal. The time period between the sale and the goods payment varied between 1 month and 7 month. In 20 percent of the deals the parties did not make an agreement on the termination of the credit. Table 8 shows that when a trade credit was given the parties agreed on it ex-ante in 16 percent of the barter deals only. In 17 percent of the cases a trade credit was given ex-post by the selling firm, because the buyer was unable or unwilling to pay.

Table 10:

\section{Barter as Credit}

\begin{tabular}{lcc}
\hline & ex ante & actual \\
& & in percent \\
\hline prepurchase & $14,9 \%$ & $14,3 \%$ \\
no termination point & $20,2 \%$ & - \\
0 month & $46,4 \%$ & $46,4 \%$ \\
1 month & $9,5 \%$ & $16,1 \%$ \\
1 - 3 months & $3,6 \%$ & $12,5 \%$ \\
3 - 7 months & $3,6 \%$ & $8,3 \%$ \\
missings & $1,8 \%$ & $2,4 \%$ \\
\hline Total & $100,0 \%$ & $100,0 \%$ \\
\hline
\end{tabular}


Table 11:

\section{Trade Credit}

Ex-Ante

in percent

\begin{tabular}{lc} 
no & 81,5 \\
yes & 16,1 \\
not applicable & 0,6 \\
missing & 1,8 \\
& 100,0 \\
Total & Ex-Post \\
\hline & in percent \\
\hline & \\
& \\
\hline & 16,7 \\
buyer was unable or unwilling to pay & 3,6 \\
seller wanted to be paid later & 76,2 \\
not applicable & 1,8 \\
other & 1,8 \\
missings & 100,0 \\
&
\end{tabular}

Source: Survey of 165 barter deals in Ukraine in 1997

Table 12 reports on the outstanding debt of bartering firms and examines whether there is a relationship between the size of the firm's outstanding debt and the extent to which the firm engages in barter. Firms who barter tend to have large outstanding bank debt, firm debt and outstanding tax arrears (exceeding 100 percent of firm sales in 1996). This suggests that these firms had little scope for obtaining further credit. If our explanation is correct, we expect a positive association between the barter share of the firm and its outstanding debt and a negative association between the barter share and bank debt. Barter can help firms with weak overall creditworthiness when they cannot get a bank loan by restoring their creditworthiness for one particular deal.

The table shows that the barter share of the firms indeed tends to increase with outstanding firm and wage arrears. At the same time barter tends to be lower for those firms which have access to bank loans. Furthermore, a simple correlation between the firm's bank debt with its firm arrears reveals a weak negative correlation between the two (the correlation coefficient is -0.185) once the state firms are excluded suggesting that firm debt helped to compensate the liquidity squeeze 
induced by low bank debt for those firms in the economy with restricted access to bank loans. ${ }^{21}$

\footnotetext{
${ }^{21}$ Calvo and Coricelli (1993) use a negative correlation between bank debt and firm arrears as evidence for whether inter-firm arrears helped to compensate for the liquidity squeeze in their argument for the role of credit as a factor explaining the output fall in Poland. According to this argument a positive correlation between bank debt and firm debt would indicate that firm debt has not alleviated the liquidity squeeze.
} 
Table 12:

Barter and Creditworthiness

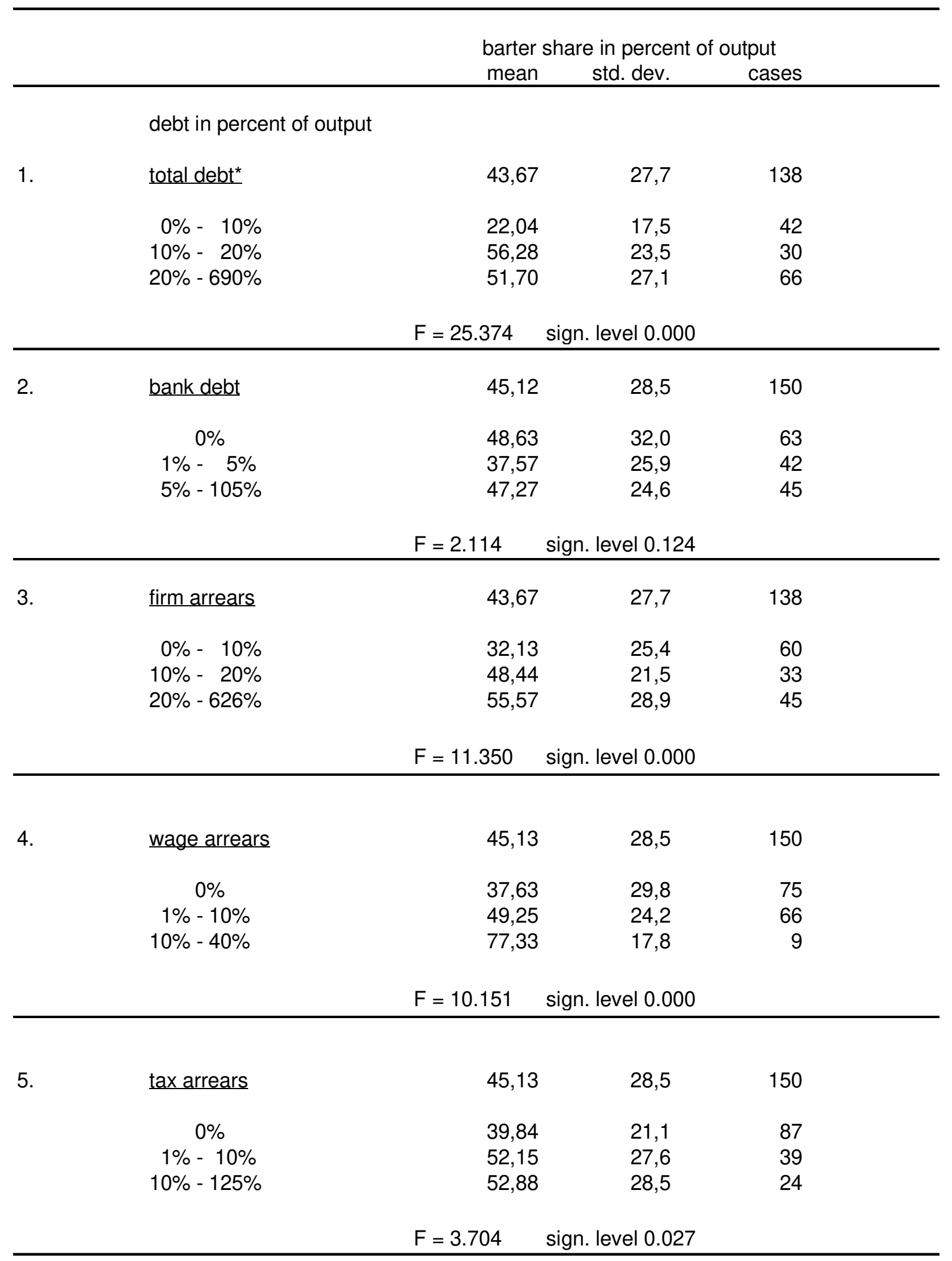

*except bank debt

Source: Survey of 165 barter deals in Ukraine in 1997. 
Next we explore whether firms in our sample have in fact faced a liquidity shortage as a limit to production. Blanchard and Kremer themselves report evidence based on a survey among 500 firms in Russia which suggests that the financial constraint was the most important shortage experienced by enterprises (see their Table IV). Between 1993 and 1995 over 60 percent of the firms experienced a shortage of financial resources compared with only over 20 percent of the firms experiencing shortages of materials. Calvo and Coricelli 1992 and 1993 have argued that credit contraction and the associated liquidity shortage have caused the output decline in Eastern Europe. ${ }^{22}$

We now turn to whether inter-enterprise arrears can be seen as a response to the liquidity crunch in the economy. If this is the case we expect inter-enterprise credit to be negatively associated with bank credit. Firms who cannot get bank credit turn to other firms for trade credit. To examine the relationship between these two types of credit in more detail we regress the share of inter-firm arrears in percent of the firm's output on the share of the firm's bank debt and a set of other variables which we consider to play a role for the size of arrears. The results are reported in Table 13. In columns 1 to 3 the results for the total sample are given. The coefficient on bank debt is positive and highly significant suggesting that firms with access to bank credit were also successful in getting inter-enterprise credit. One of the reasons why the two types of credit move in the same direction is the ownership status of the firm. Rostowski 1993 and others have argued that arrears are simply a manifestation of soft budget constraints. To control for this possibility we divide the sample into private and state firms and rerun the regressions. It turns out that for private firms inter-firm credit cushioned the liquidity contraction induced by lower bank credit (see columns 4 and 5 of Table 13). State firms in contrast appear to be able to use their privileged status of creditworthiness to get cash credits from banks as well as trade credits from other firms (columns 6 and 7).

As we have argued in the previous section two additional variables are supposed to have contributed to the size of arrears: the firm's barter exposure and the complexity of the firm's production. Barter trade is an inter-enterprise credit repaid in goods rather than money. Thus at some critical level of arrears the only way firms' arrears can grow further is if they undertake barter. If our explanation of barter is correct, we expect a positive coefficient on the barter share. This is indeed the case for the overall sample and the two subsamples of firms (columns 2 and 3, 4 and 5, 6 and 7 of Table 13).

Next, we included the index of complexity into the equation. As we argued in the previous section, arrears are expected be more pronounced for firms with more

\footnotetext{
${ }^{22}$ Calvo and Coricelli run a regression between output and credit for Poland. They get a point estimate between 0.2 and 0.6 depending on specification which suggests that a 10 percent contraction of credit results in an output decline between 2 and 6 percent.
} 
complex production structures, since their liquidity constraint is supposed to help them to deal with the hold up problem. This appears to be supported by the data. Finally, we rerun the regressions with total arrears (including wage and tax arrears) rather than firms' arrears alone as the dependent variable with very similar results. The data seem to suggest that Ukrainian firms in fact experienced a liquidity squeeze which barter has helped to alleviate. 
Table 13:

Barter, Arrears and Liquidity Sqeeze

\begin{tabular}{|c|c|c|c|c|c|c|c|c|c|c|c|c|c|c|}
\hline & & & & rm arrear & & & & & & & tal arrear & & & \\
\hline & & all firms & & priva & firms & $\underline{\text { stat }}$ & rms & & all firms & & priva & firms & $\underline{\text { state }}$ & ims \\
\hline & $(1)$ & (2) & (3) & (4) & $(5)$ & (6) & (7) & (8) & (9) & (10) & (11) & (12) & (13) & (14) \\
\hline bank debt & $\begin{array}{c}2,61 \\
(0,000)\end{array}$ & $\begin{array}{c}2,40 \\
(0,000)\end{array}$ & $\begin{array}{c}2,61 \\
(0,000)\end{array}$ & $\begin{array}{c}-1,77 \\
(0,132)\end{array}$ & $\begin{array}{c}-1,77 \\
(0,279)\end{array}$ & $\begin{array}{c}2,27 \\
(0,007)\end{array}$ & $\begin{array}{c}3,64 \\
(0,000)\end{array}$ & $\begin{array}{c}3,72 \\
(0,000)\end{array}$ & $\begin{array}{c}3,54 \\
(0,000)\end{array}$ & $\begin{array}{c}3,72 \\
(0,000)\end{array}$ & $\begin{array}{c}-4,17 \\
(0,167)\end{array}$ & $\begin{array}{c}-9,02 \\
(0,020)\end{array}$ & $\begin{array}{c}3,42 \\
(0,000)\end{array}$ & $\begin{array}{c}4,80 \\
(0,000)\end{array}$ \\
\hline barter & $\begin{array}{c}0,92 \\
(0,001)\end{array}$ & $\begin{array}{c}0,90 \\
(0,001)\end{array}$ & $\begin{array}{c}0,92 \\
(0,001)\end{array}$ & $\begin{array}{c}0,49 \\
(0,000)\end{array}$ & $\begin{array}{c}0,48 \\
(0,001)\end{array}$ & $\begin{array}{c}2,57 \\
(0,003)\end{array}$ & $\begin{array}{c}2,22 \\
(0,004)\end{array}$ & $\begin{array}{c}1,07 \\
(0,000)\end{array}$ & $\begin{array}{c}1,06 \\
(0,000)\end{array}$ & $\begin{array}{c}1,07 \\
(0,000)\end{array}$ & $\begin{array}{c}0,40 \\
(0,027)\end{array}$ & $\begin{array}{c}0,67 \\
(0,005)\end{array}$ & $\begin{array}{c}2,67 \\
(0,003)\end{array}$ & $\begin{array}{c}2,32 \\
(0,004)\end{array}$ \\
\hline complexity & $\begin{array}{l}117,59 \\
(0,047)\end{array}$ & $\begin{array}{l}120,36 \\
(0,041)\end{array}$ & $\begin{array}{l}117,64 \\
(0,048)\end{array}$ & & $\begin{array}{c}7,70 \\
(0,848)\end{array}$ & & $\begin{array}{l}748,54 \\
(0,001)\end{array}$ & $\begin{array}{l}135,87 \\
(0,024)\end{array}$ & $\begin{array}{l}138,20 \\
(0,000)\end{array}$ & $\begin{array}{l}135,85 \\
(0,025)\end{array}$ & & $\begin{array}{l}195,70 \\
(0,040)\end{array}$ & & $\begin{array}{l}755,12 \\
(0,001)\end{array}$ \\
\hline state & & $\begin{array}{c}23,57 \\
(0,148)\end{array}$ & & & & & & & $\begin{array}{c}19,78 \\
(0,233)\end{array}$ & & & & & \\
\hline private & & & $\begin{array}{c}0,53 \\
(0,984)\end{array}$ & & & & & & & $\begin{array}{c}-0,19 \\
(0,994)\end{array}$ & & & & \\
\hline $\mathrm{R}^{2}$ Adj. & 0,224 & 0,229 & 0,218 & 0,874 & 0,829 & 0,242 & 0,404 & 0,344 & 0,346 & 0,340 & 0,467 & 0,610 & 0,345 & 0,482 \\
\hline $\mathrm{N}$ & 149 & 149 & 149 & 13 & 12 & 49 & 49 & 151 & 151 & 151 & 14 & 13 & 49 & 49 \\
\hline
\end{tabular}

${ }^{1)}$ The number of cases exceeds the number of interviewed firms because each barter deal involves a selling and a buying firm.

Source: Survey of 165 barter deals among 55 Ukrainian firms in 1997 


\section{Conclusions}

In this paper we have explored several explanations for the explosion of barter in postsocialist economies: soft budget constraints, lack of restructuring, the virtual economy, and tax avoidance. Of these explanations only the tax reason for barter is weakly supported by the data. The tax argument for barter can, however, not explain why barter exploded from about 5 percent to 60 percent within four years. Something else is at work here and from our survey data in the Ukraine the following picture has emerged.

Barter is mainly driven by financial considerations. Firms lack the cash to pay for their inputs and banks refuse to provide capital. This has led to the phenomenon of inter-firm arrears in which firms extend trade credits to each other. We have argued that these firmarrears allowed intermediate producers to deal with the problem of trust in the economy and found supporting evidence for this role of arrears. We argued further that barter comes into play when arrears become so critically large that firms will refuse to extend further trade credits to their buyers out of the worry of not being paid. By introducing a hostage barter then allows the debtor firm to make a commitment to repay the loan and thus restores creditworthiness for one specific deal at the time rather than for the firms overall. We found evidence to support this view of barter.

The view of barter as a substitute for a banking failure suggests the following explanation for the evolution of barter over time: The arrears crisis in Russia evolved in 1992 while barter started to rise in 1994. Barter started to rise in 1994 because around this time arrears reached a critical level at which production was unsustainable. Our data suggest that this critical level was reached when arrears were around 30 to 40 percent of firm's sales. At this point firms refused to extend further credit to each other. Barter then stepped in as the only way to maintain production. At this point barter started to substitute for the non active banking sector as well as for trade credits in cash which explains the explosive increase.

Given this story of the role of barter in transition economies what follows for policy? Barter seems to have established itself as an economic institution to deal with the banking failure and capital markets imperfections in transition economies. We have argued that barter has produced short term benefits by allowing these economies to maintain or increase production without a functioning banking sector. However, the short term efficiency gain might come at the costs of long term efficiency losses. Barter might have established itself as an institution which hinders the banking sector from developing. This transition trap might arise because banks will not have an incentive to enter the market given the existence of barter. 
A major challenge in the transition to a market system is the replacement of a centralized credit system with decentralized financial discipline. We argue elsewhere that a decentralized banking system creates a coordination problem that a multi-banking system cannot handle. Creditors may be more likely to finance credit-constrained firms under a financial system based on long-term relationships than one based on arms-length transactions. There may be particular value therefore for such transition economies as Russia and Ukraine in the development of a German type banking system to avoid such a transition trap. ${ }^{23}$

Reforming the banking sector in the former Soviet Union in order to remonetize their economies is urgent. Short term macroeconomic 'fixes' such as expansionary monetary policy to overcome the liquidity shortage in these economies would make matters worse. In a barter economy a monetary expansion may have perverse effects. The reason is that reducing arrears by infusing liquidity into the economy is likely to reduce intermediate producers' bargaining power thereby taking away an instrument to deal with disorganization and the trust problem. In other words, a monetary expansion in a barter economy works like introducing partial reform in an overall distorted economy. ${ }^{24}$

\footnotetext{
${ }^{23}$ For the argument see Huang, Marin, and Xu (1999).

${ }^{24}$ For the argument why partial reform might make things worse in an overall distorted economy see Murphy, Shleifer, and Vishny (1992).
} 


\section{Bibliography}

Anderson, R.W., Berglöf, E. and Mizsei, K. (1996), Banking Sector Development in Central and Eastern Europe, Economic Policy Initiative No. 1/CEPR

Begg, D. and Portes, R. (1993), Enterprise Debt and Economic Transformation: Financial Restructuring in Central and Eastern Europe, in: C. Mayer and X. Vives (eds) Capital Markets and Financial Intermediation, Cambridge University Press

Blanchard, O. and Kremer, M. (1997) Disorganization, The Quarterly Journal of Economics, Nov. 97

Calvo, G.A. and Frenkel, J.A. (1991), Credit Markets, Credibility, and Economic Transformation, Journal of Economic Perspectives, Vol. 5, (4), pp. 139-148

Calvo, G.A. and Coricelli, F. (1993), Output Collapse in Eastern Europe: The Role of Credit, in: M.I. Blejer, G.A. Calvo, F. Corricelli and A.H. Gelb (eds), Eastern Europe in Transition: From Recession to Growth? World Bank Discussion Paper 196, World Bank, Washington, DC

Calvo, G.A. and Coricelli, F. (1995) Inter-Enterprise Arrears in Economies in Transition, in R. Holzmann, J. Gacs and G. Winckler (eds.): (1995): Output Decline in Eastern Europe. Unavoidable, External Influence or Homemade?, Kluwer, London

Commander, S. and Mummsen, C. (1998) Understanding Barter in Russia, European Bank for Reconstruction and Development, London, mimeo.

European Bank of Reconstruction and Development, Transition Report 1997, pp. 26-27

Gaddy, C.G. and Ickes, B.W. (1998) Russia's Virtual Economy, Foreign Affairs, Vol.77 No. 5, pp. 53- 67.

Greif, A. and Kandel, E. (1994), Contract Enforcement Institutions: Historical Perspective and Current Status in Russia, Chapter 8, in: E. Lazar (ed.) Economic Transition in Eastern Europe and Russia: Realities of Reform, Stanford CA 
Hay, J.R. and Shleifer, A. (1998), Government in Transition: Private Enforcement of Public Laws: A Theory of Legal Reform, American Economic Review, Vol 88 (2), 398-403

Hellman, J., Jones, G., and Kaufmann, D. (1999), Political Capture, State and Firms in Transition: Evidence on Governance from an Enterprise Survey. (Forthcoming).

Huang, H., Marin, D., and Xu, C. (1999), A Transition Trap? Barter and the Development of Banking, International Monetary Fund, University of Munich, and London School of Economics, mimeo.

Ickes, B.W. and Ryterman, R. (1992), The Inter-Enterprise Arrears Crisis in Russia, PostSoviet Affairs, 8 (4), pp. 331-361

Ickes, B.W. and Ryterman, R. (1993), Roadblock to Economic Reform: Inter-Enterprise Debt and the Transition to Markets, Post-Soviet Affairs, 9 (3), pp. 231-252

Johnson, S., Kaufmann, D. and Shleifer, A. (1997), The Unofficial Economy in Transition, Brookings Papers on Economic Activity, Fall (2), 1997, pp. 159-239

Johnson, S., Kaufmann, D. , Zoido-Lobaton, P. (1998), Regulatory Discretion and the Unofficial Economy, American Economic Review, May 1998, Vol. 88, No. 2, pp.387392

Kaufmann, D. and Marin, D. (1999), The Non-Cash Economy: Evidence from 20 Transition Economies, The World Bank and University of Munich, mimeo.

Kranton, R.E. (1996), Reciprocal Exchange: A Self-Sustaining System, American Economic Review, Sept. 96, 86 (4)

Marin, D. (1990) Tying in International Trade, The World Economy, 13(3), pp 445-62. 
Marin, D. and Schnitzer, M. (1995) Tying Trade Flows: A Theory of Countertrade, Amercian Economic Review, 85/5, pp. 1047-1064

Marin, D. and Schnitzer, M. (1997), The Economic Institution of International Barter, Centre for Economic Policy Research CEPR, Discussion Paper No. 1658, London

Marin, D. and Schnitzer, M (1999), Disorganization and Financial Collapse, Centre for Economic Policy Research CEPR, Discussion Paper No. 2245, London.

Mitchell, J. (1993) Creditor Passivity and Bankruptcy: Implications for Economic Reform, in: C. Mayer and X. Vives (eds) Capital Markets and Financial Intermediation, Cambridge University Press

Murphy, K., Shleifer, A. and R. Vishny (1992), The Transition to a Market Economy: Pitfalls of Partial Reform, Quarterly Journal of Economics, CVII (3), pp. 889-906.

Perotti, E.C. (1995), Inertial Credit and Opportunistic Arrears in Transition, European Economic Review .

Russian Economic Barometer (1997), Survey of Industrial Firms, Institute of World Economy and International Relations, Moscow

Rostowski, J. (1993), The Inter-Enterprise Debt Explosion in the Former Soviet Union: Causes, Consequences, Cures. Centre for Economic Performance/ESRC Discussion Paper No. 142

Williamson, O.E.(1983), Credible Commitments: Using Hostages to support Exchange. American Economic Review, September 1983, 73 (4) 519-40 